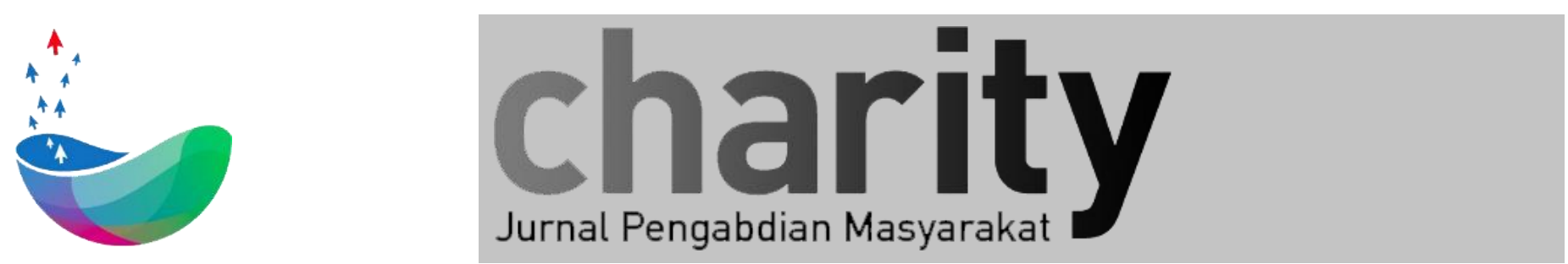

\title{
PELATIHAN MENYUSUN KONTEN MULTIMEDIA INTERAKTIF UNTUK PARA GURU SDIT BINA INSAN CENDIKIA KELURAHAN LEUWIGAJAH KOTA CIMAHI
}

\author{
Mukhammad Ramdlan Kirom ${ }^{1}$, Edy Wibowo ${ }^{1}$, Ahmad Qurthobi ${ }^{1}$, Linahtadiya Andiani ${ }^{1}$ \\ ${ }^{1}$ Program Studi Teknik Fisika, Fakultas Teknik Elektro, Universitas Telkom \\ mramdlankirom@telkmuniversity.ac.id, edywibowo@telkomuniversity.ac.id, qurthobi@telkomuniversity.ac.id, linahtadiyaa@telkomuniversity.ac.id
}

\section{INFO ARTIKEL}

Diterima 16 September 2021

Direvisi 06 Oktober 2021

Disetujui 15 Oktober 2021

Tersedia Online 20 November 2021
Keyword: pandemi Covid-19, pelatihan, pembelajaran daring, materi multimedia interaktif

\begin{abstract}
ABSTRAK
Kondisi saat ini dengan adanya pandemi Covid-19 hampir semua aspek kehidupan manusia terdampak. Salah satu aktivitas yang terpengaruh adalah proses belajarmengajar di sekolah-sekolah, di mana biasanya dilakukan di kelas menjadi kegiatan pembelajaran di rumah berbasis daring. Jika proses pembelajaran di kelas, para guru dapat menjelaskan secara verbal dan bisa dibantu dengan alat peraga tentang materi tertentu. Hal ini tidak bisa dilakukan jika pembelajaran yang diberikan secara daring. Kasus ini dialami para guru yang ada di Sekolah Dasar Islam Terpadu Bina Insan Cendikia (SDIT-BIC) Cisalak Kelurahan Leuwigajah Kecamatan Cimahi Selatan Kota Cimahi. Para guru di SDIT-BIC saat ini menyampaikan pembelajaran hanya sebatas instruksi kepada murid untuk mempelajari materi dari buku atau bisa mencari materi dari internet. Hal ini tentu saja tidak bisa optimal dari aspek pemahaman mahasiswa. Sisi buruknya si anak atau murid tidak terpacu untuk belajar karena banyak hal yang tidak dipahami oleh murid. Berkaitan dengan ini pada tahap awal akan diberikan bagaimana membuat materi multimedia interaktif di mana bisa dibuat animasi sederhana untuk menerangkan materi menggunakan Microsoft Power Point. Pelatihan dilakukan sebagai transfer ilmu dan pengalaman tim penulis dalam menyusun materi kuliah daring. Kegiatan pelatihan diawali dengan diskusi antara para guru dengan tim penulis berkaitan kendala dalam penyampaian materi dan dilanjutkan dengan pelatihan menyusun materi multimedia interaktif. Selanjutnya para guru diminta membuat konten dan dievaluasi oleh tim penulis. Dari beberapa materi yang disusun sudah terlihat berupa materi multimedia interaktif.
\end{abstract}

Korespondensi:

Direktorat Penelitian dan Pengabdian Masyarakat, Universitas Telkom

J1. Telekomunikasi No. 1, Terusan Buah Batu, Bandung, 40257

Indonesia

E-mail : ppm@telkomuniversity.ac.id

ORCID ID:

Penulis Pertama: Mukhammad Ramdlan Kirom

https:// 10.25124/charity.v4i2a

Paper_reg_number xxx (C) The Authors. Published by Directorate of Research and Community Service, Telkom University.

This is an open access article under the $\mathrm{xxx}$ license (https://creativecommons.org/licenses/xxx) 


\section{Pendahuluan}

Sekolah Dasar Islam Terpadu (SDIT) Bina Insan Cendikia berdiri pada tahun 2016 dengan jumlah guru 15 orang. Di sekolah SDIT ini, dengan masa berdirinya yang masih baru dan juga guru yang ada saat ini umumnya masih baru juga. Potensi yang dimiliki SDIT Bina Ihsan Cendikia Cisalak Kelurahan Leuwigajah Cimahi saat ini adalah fasilitas fisik sudah cukup baik dan dari aspek sumber daya manusia, yaitu para guru yang ada masih usia muda. Salah satu kendala adalah dari para guru tidak mempunyai keahlian dalam metodologi pengajaran dikarenakan latar belakang para guru tidak semuanya berasal dari perguruan tinggi keguruan.

Pada awal tahun 2020 terjadi penyebaran virus Corona Virus Disease (Covid-19) yang menyebabkan terjadi perubahan signifikan untuk setiap aktivitas di masyarakat, termasuk pada aktivitas pendidikan. Pemerintah Indonesia melalui Menteri Pendidikan menerbitkan peraturan No 4 Tahun 2020 Tentang Pelaksanaan Kebijakan Pendidikan dalam Masa Darurat Penyebaran Covid-19 di mana proses belajar harus dilaksanakan dari rumah masing-masing baik murid ataupun guru melalui pembelajaran daring/jarak jauh. Dengan demikian terjadi perubahan metode pembelajaran di mana siswa harus mengakses materi secara daring sehingga terjadi perubahan kebiasaan aktivitas di rumah. Selain itu juga perlu adanya fasilitas yang menunjang kegiatan seperti telepon pintar dan jaringan internet.

Kondisi saat ini masalah pandemik virus Covid-19 masih belum teratasi dan seperti sekolah-sekolah yang lain juga dialami oleh SDIT Bina Ihsan Cendikia. Sejauh ini materi penyampaian berupa tugas yang diberikan melalui aplikasi Whatsapp dan video interaktif menggunakan aplikasi Zoom atau Google Meet. Hal ini ternyata mempunyai beberapa permasalahan, seperti fasilitas jaringan internet, tingkat pemahaman siswa dalam menggunakan perangkat, minimnya pengetahuan para guru dalam menyampaikan pelajaran secara daring, dan bahan pembelajaran yang belum mendukung pembelajaran secara daring.

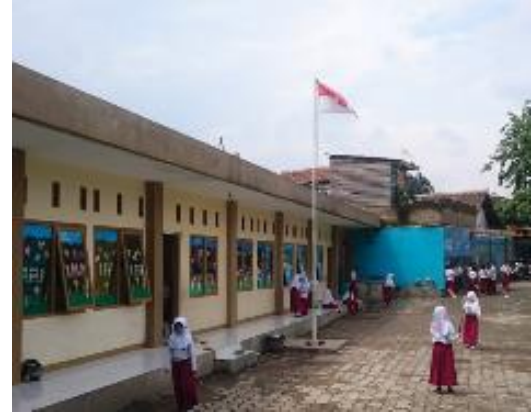

(a)

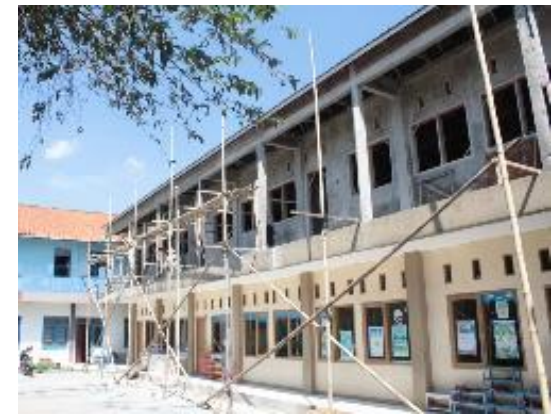

(b)

Gambar 1. (a) Kondisi sekolah SDIT Bina Ihsan Cendikia saat sebelum pandemik Covid-19, (b) Kondisi saat pandemik Covid-19 sedang renovasi

Berdasarkan permasalahan di atas yang akan disasar dan dicari solusinya oleh tim pengabdian pada masyarakat adalah bagaimana meningkatkan kreativitas guru dalam mengembangkan media dan bahan ajar sehingga sesuai dengan tujuan pengajaran dengan memanfaatkan media daring. Dari konsep Learning Pyramid yang menyatakan bahwa efektifivitas pengajaran sangat 
ditentukan dari ikut sertanya siswa secara aktif dalam kegiatan belajar seperti demonstrasi, diskusi, simulasi, dan pengalaman langsung. Dengan demikian para guru diharapkan mampu mengemas media, bahan ajar, dan cara penyampaian dalam bentuk seperti di atas. Pemanfaatan Teknologi Informasi dan Komunikasi (TIK) untuk pendidikan dapat dinyatakan dalam tiga kategori, yaitu sebagai sistem pembelajaran, media pembelajaran, dan sebagai sumber bahan ajar. Sebagai sistem pembelajaran seperti e-learning, online learning, virtual learning, dan sebagainya. Sedangkan sebagai media pembelajaran seperti simulasi, presentasi multimedia, animasi, dan lain-lain. Untuk sumber bahan ajar seperti buku elektronik, ensiklopedia online, dan bahan yang tersedia di internet.

Program pengabdian masyarakat ini diharapkan memberikan solusi permasalahan berkaitan dengan metode pembelajaran secara daring bagi para guru yang ada di SDIT Bina Ihsan Cendikia Cisalak Kelurahan Leuwigajah Cimahi. Kegiatan ini berupa pelatihan untuk para guru agar dapat menyusun sendiri materi untuk disampaikan ke murid masing-masing saat menyampaikan materi secara daring dengan memanfaatkan TIK. Pelatihan yang diberikan bertujuan memberikan bekal bagi para guru untuk dapat menyusun materi multimedia agar murid lebih mudah memahami materi yang diajarkan. Namun, untuk mudah dipahami oleh murid perlu dikaji, diuji, dan dievaluasi materi tersebut terutama media komunikasi efektif dengan murid berkaitan dengan media tulisan, media gambar, suara, atau video. Berarti yang paling penting adalah bagaimana menyusun materi interaktif agar mudah dipahami murid. Pelatihan ini lebih ke bagaimana menyusun materi multimedia, belum ke arah menyusun materi yang interaktif. Berikutnya dapat diberikan pelatihan bagaimana mengevaluasi materi pembelajaran agar interaktif dan lebih mudah dipahami murid.

\section{Pelaksanaan}

Pelaksanaan kegiatan dilakukan dalam bentuk kegiatan tatap muka di SDIT Bina Ihsan Cendikia Cisalak Kelurahan Leuwigajah Cimahi dan kegiatan bimbingan secara daring menggunakan aplikasi Google Class Room (GCR). Kegiatan tatap muka dilaksanakan pada tanggal 12 November 2021 dan kegiatan bimbingan dari dilaksanakan 1 bulan setelah pelaksanaan tatap muka.

Sebelum pelaksanaan kegiatan pelatihan di atas dilakukan pertemuan awal untuk koordinasi dengan pihak sekolah berkaitan program pengabdian yang dilaksanakan dan manfaat yang dapat diperoleh oleh pihak sekolah. Selanjutnya memastikan ada ruang yang dapat digunakan untuk kegiatan pelatihan yang representatif mengingat sedang dalam masa pandemi Covid 19. Setelah itu didiskusikan kapan pelaksanaan yang memungkinkan dapat dilakukan dengan menyesuaikan agenda dengan pihak sekolah.

Kegiatan dibuat dalam bentuk tatap muka selama 3 jam dan bimbingan secara daring bertujuan untuk mengurangi aktivitas dalam kerumunan dalam waktu yang lama. Kegiatan tatap muka perlu dilakukan terutama untuk mempermudah proses awal dalam memberi pemahaman kepada para guru dan untuk menggali lebih dalam lagi kesulitan yang umum dirasakan oleh para guru dalam menerangkan materi pelajaran secara daring kepada siswa. Dalam 
kegiatan tatap muka tersebut dijelaskan media, metode, dan bahan ajar dalam pembelajaran secara daring. Selanjutnya diberikan materi contoh menyusun materi multimedia menggunakan Microsoft Powerpoint sederhana dan selanjutnya para guru diminta menyusun materi seperti contoh dan dikumpulkan sebagai tugas di GCR. Dilakukan monitoring dalam penyusunan materi yang diharapkan dapat dikumpulkan dalam waktu 2 minggu dan dilakukan evaluasi dari hasil penyusunan materi tersebut dalam forum diskusi di GCR.

\section{Metode}

Metode pelatihan yang dilakukan agar para guru dapat memahami materi yang diberikan dan menjadi solusi dari permasalahan berkaitan dengan metode pembelajaran secara daring adalah pendekatan partisipatif. Pendekatan partisipatif merupakan pendekatan di mana para guru dilibatkan dalam penyusunan kegiatan, pelaksanaan kegiatan, dan evaluasi hasil. Tim Pengabdian Pada Masyarakat berperan untuk memandu para guru dalam menyusun materi pembelajaran online. Keterlibatan mitra sebagai wujud dari partisipasi berupa penyediaan tempat pelatihan, keterlibatan dalam kegiatan, dan menyusun draft dari materi pembelajaran untuk dievaluasi.

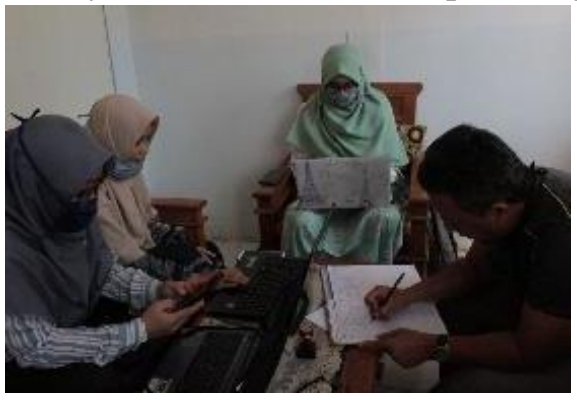

(a)

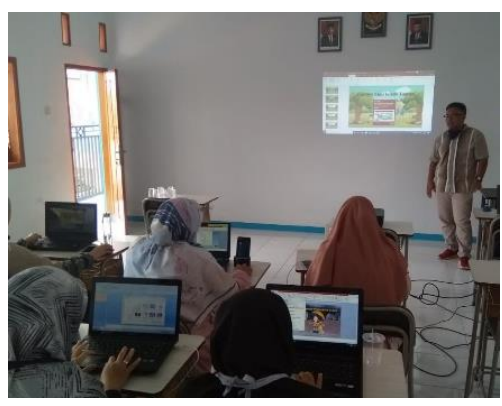

(b)

Gambar 2. (a) Diskusi dengan mitra berkaitan dengan persiapan kegiatan pelatihan, (b) pelaksanaan pelatihan

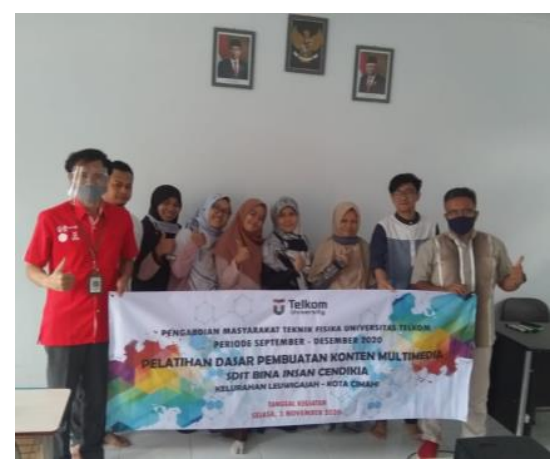

(a)

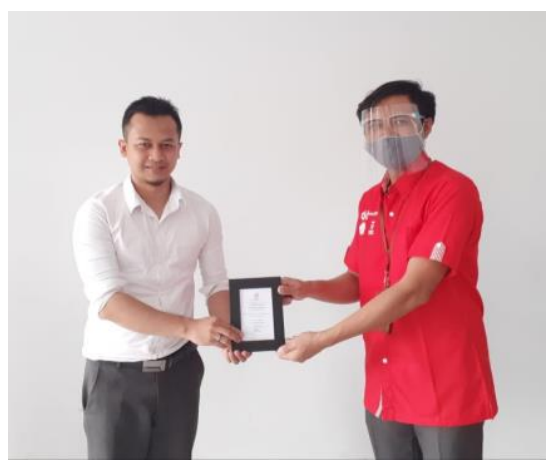

(b)

Gambar 3. (a) Foto bersama setelah pelaksanaan pelatihan, (b) serah terima plakat dari pihak mitra

Sebelum kegiatan pelatihan diberikan quesioner kepada para peserta untuk melihat pemahaman dan metode pengajaran yang sudah dilaksanakan sebelumnya. Dari hasil quesioner tersebut diketahui semua peserta pernah dan 
sering menyampaikan materi pelajaran secara daring menggunakan aplikasi Whatsapp, Google Class Room, Google Form, Google Slide, Youtube, dan lain-lain. Sedangkan untuk belajar tatap muka secara daring menggunakan Google Meets dan Zoom. Sedangkan untuk penyampaian materinya sendiri sudah ada beberapa orang yang menggunakan animasi interaktif. Dari hasil ini dapat diketahui pemahaman tentang metode pembelajaran secara daring sudah dipahami dengan baik.
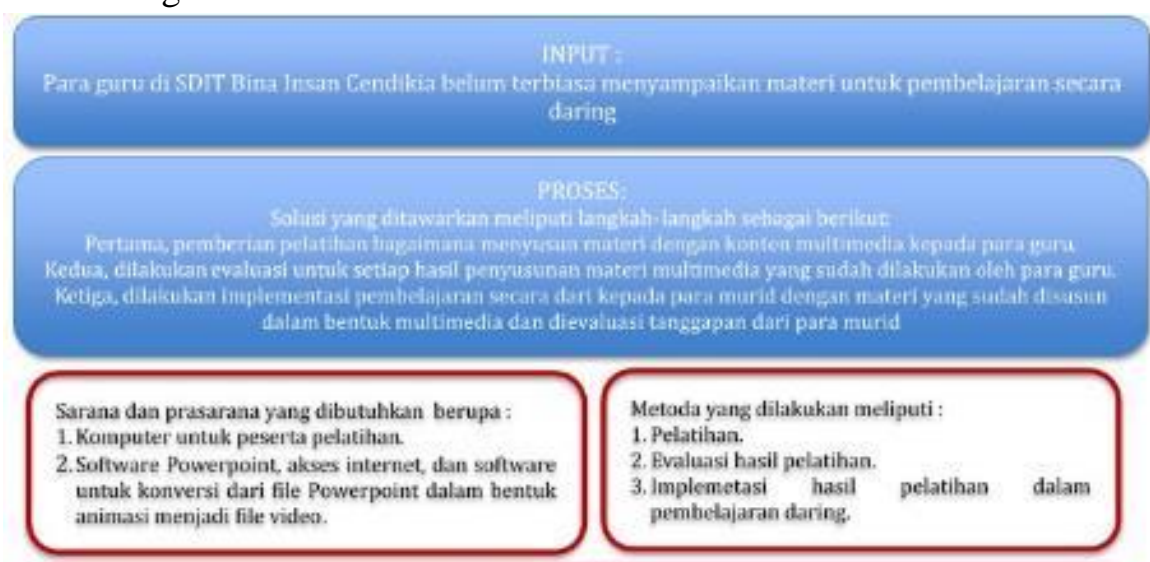

Kegiatan yang dilakukan dalam rangka memberikan solusi meliputr:

- Pelatilsan dari pihalk kampus dan diskusi dengan para guru dalan mengevaluasi hasil pelatihan

- Implementasi materi yang disusen hasil pelatihan pada para gura kepada murid.

- Evaluasi dan hasil respon para murid.

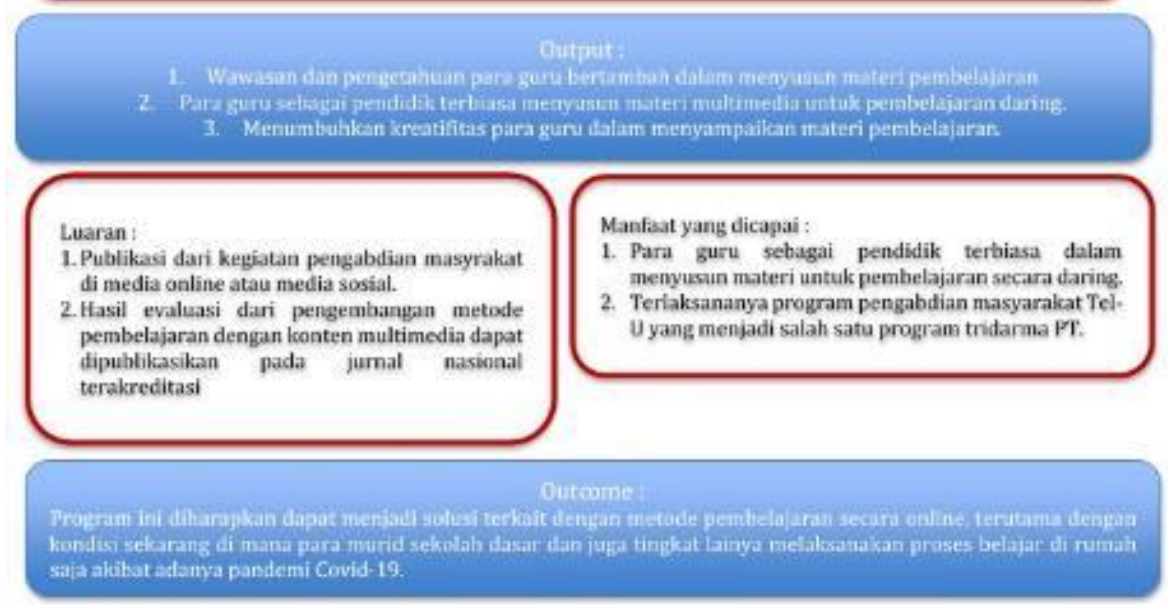

Gambar 4. Gambaran IPTEK yang akan ditransfer ke mitra

\section{Hasil dan Evaluasi}

Sebagai bahan evaluasi, para peserta diminta untuk membuat konten interaktif sebagai dan dikumpulkan melalui Google Class Room untuk dievaluasi sejauh mana pemahaman dan kreativitas peserta dalam menyiapkan materi pembelajaran. Karena peserta pelatihan ini adalah para guru Sekolah Dasar maka diharapkan disesuaikan dengan minat dan ketertarikan siswa SD untuk mudah memahami materi yang diberikan. 


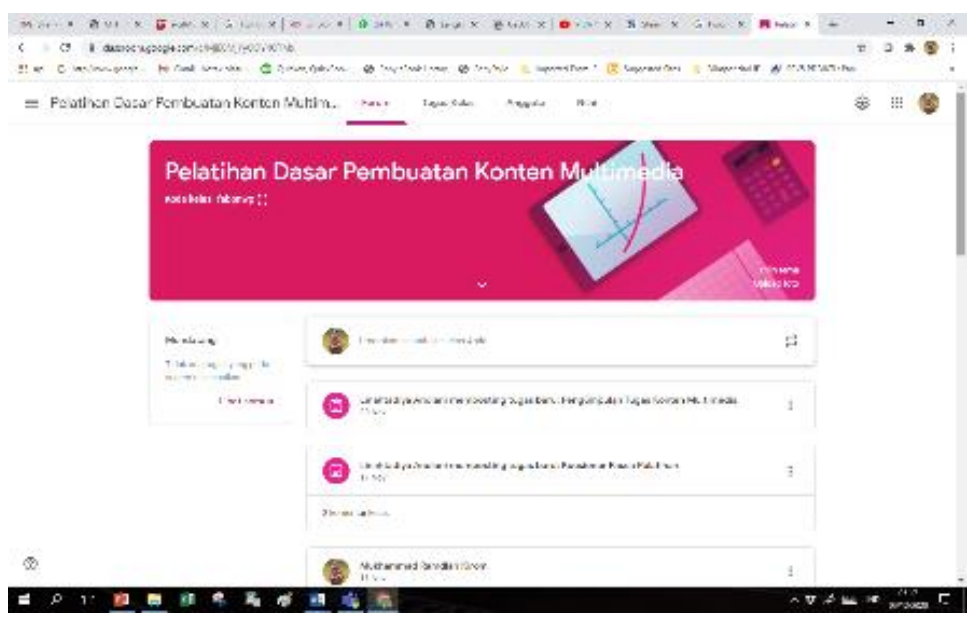

Gambar 5. Screenshoot dari Google Class Room yang digunakan untuk mengumpulkan hasil pembuatan konten interaktif dan evaluasinya

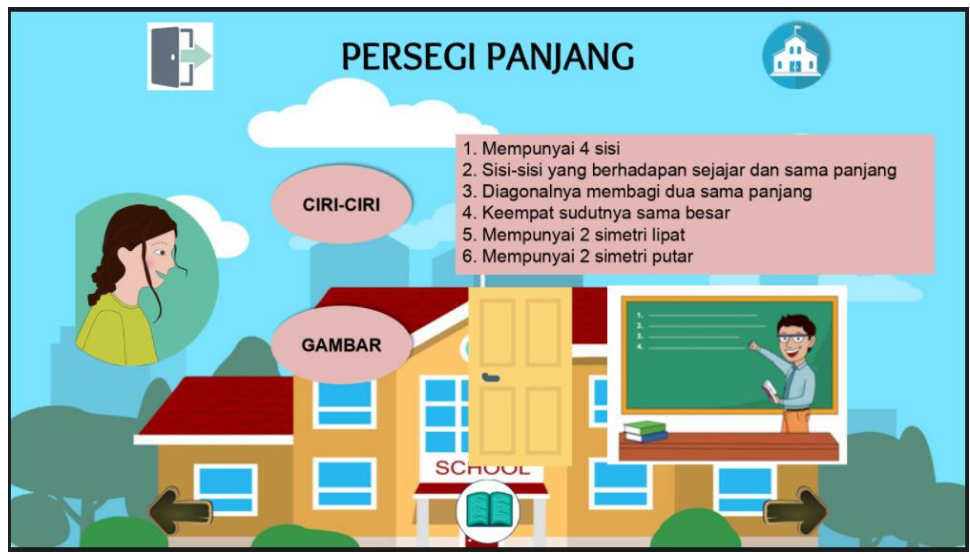

Gambar 6. Screenshoot dari contoh konten interaktif yang sudah dibuat oleh peserta pelatihan

Berdasarkan hasil diskusi secara lisan, para peserta merasa antusias dengan adanya kegiatan pelatihan konten multimedia untuk proses belajar-mengajar. Beberapa dari peserta merasa sangat senang karena implementasi konten multimedia untuk proses pembelajaran dapat dilakukan hanya dengan menggunakan perangkat lunak yang sudah umum digunakan pada proses pembelajaran sehari-hari. Selanjutnya berikut ini hasil kuisioner setelah pelaksanaan.

Tabel 1. Hasil kuesioner setelah pelatihan

\begin{tabular}{|c|c|c|c|}
\hline $\begin{array}{l}\text { BUTIR-BUTIR PENILAIAN } \\
(\text { FEEDBACK) }\end{array}$ & $\begin{array}{l}\text { TIDAK } \\
\text { SETUJU }\end{array}$ & $\begin{array}{l}\text { KURANG } \\
\text { SETUJU }\end{array}$ & SETUJU \\
\hline $\begin{array}{l}\text { 1. Secara keseluruhan kegiatan } \\
\text { pelatihan ini bermanfaat bagi } \\
\text { Bapak/Ibu. }\end{array}$ & $0 \%$ & $0 \%$ & $100 \%$ \\
\hline $\begin{array}{l}\text { 2. Rangkaian kegiatan pelatihan } \\
\text { ini menarik. }\end{array}$ & $0 \%$ & $0 \%$ & $100 \%$ \\
\hline $\begin{array}{l}\text { 3. Bapak/Ibu antusias mengikuti } \\
\text { seluruh acara pelatihan }\end{array}$ & $0 \%$ & $0 \%$ & $100 \%$ \\
\hline
\end{tabular}




\begin{tabular}{|c|c|c|c|c|}
\hline & $\begin{array}{l}\text { Materi yang telah diberikan } \\
\text { selama pelatihan sesuai } \\
\text { dengan topik. }\end{array}$ & $0 \%$ & $0 \%$ & $100 \%$ \\
\hline & $\begin{array}{l}\text { Fasilitas yang tersedia selama } \\
\text { acara pelatihan baik dan } \\
\text { memadai. }\end{array}$ & $0 \%$ & $0 \%$ & $100 \%$ \\
\hline & $\begin{array}{l}\text { Saudara puas dengan } \\
\text { penyelenggaraan pelatihan ini. }\end{array}$ & $0 \%$ & $0 \%$ & $100 \%$ \\
\hline & PERTANYAAN & \multicolumn{3}{|c|}{ JAWABAN } \\
\hline & $\begin{array}{l}\text { Adakah kesan yang Saudara } \\
\text { dapat dari penyelenggaraan } \\
\text { pelatihan ini? }\end{array}$ & \multicolumn{3}{|c|}{$\begin{array}{l}\text { 1. Seru dan perlu ada lanjutannya } \\
\text { lagi. } \\
\text { 2. Alhamdulillah bertambahnya } \\
\text { ilmu dalam membuat konten } \\
\text { multimedia. }\end{array}$} \\
\hline & $\begin{array}{l}\text { Adakah kritik dan saran yang } \\
\text { ingin Saudara berikan untuk } \\
\text { penyelenggaraan pelatihan ke } \\
\text { depannya? }\end{array}$ & \multicolumn{3}{|c|}{$\begin{array}{l}\text { 1. Request topik mengenai } \\
\text { pembelajaran numerik. } \\
\text { 2. Semoga pelatihan berikutnya bisa } \\
\text { memberikan pelatihan yang lebih } \\
\text { menarik dan seru lagi dengan } \\
\text { memberika cara yang lebih seru } \\
\text { lagi }\end{array}$} \\
\hline
\end{tabular}

Berdasarkan hasil diskusi secara lisan, para peserta merasa antusias dengan adanya kegiatan pelatihan konten multimedia untuk proses belajar-mengajar. Beberapa dari peserta merasa sangat senang karena implementasi konten multimedia untuk proses pembelajaran dapat dilakukan hanya dengan menggunakan perangkat lunak yang sudah umum digunakan pada proses pembelajaran sehari-hari. Dari hasil pelaksanaan pelatihan ini serta dari apa sudah dibuat oleh peserta sudah memperlihatkan materi yang cukup interaktif.

\section{Kesimpulan dan Saran}

Kegiatan pengabdian masyarakat yang telah dilakukan di SDIT Bina Ihsan Cendikia Cisalak Kelurahan Leuwigajah Cimahi ini telah memberikan wawasan baru bagi para guru di sekolah tersebut dalam mengembangkan konten pembelajaran interaktif. Materi pembelajaran yang interaktif ini penting karena pembelajaran yang efektif adalah ikut sertanya siswa secara aktif dalam kegiatan belajar. Oleh karena itu tiap guru harus menguasai dalam penyusunan materi pembelajaran interaktif ini. Penggunaan aplikasi Microsoft Powerpoint yang mempunyai fitur untuk menyampaikan materi secara multimedia mudah dipahami oleh para guru dalam meyusun konten pembelajaran interaktif sesuai dengan hasil evaluasi dari konten yang sudah dibuat.

Dari hasil kegiatan ini belum dilakukan pengamatan sejauh mana efektifitas konten interaktif yang dibuat para guru ini terhadap pemahaman siswa. Oleh karena itu disarankan untuk melakukan pengukuran dan evaluasi hal tersebut di atas pada kegiatan pengabdian masyarakat selanjutnya.

Kami ucapkan terima kasih kepada Universitas Telkom melalui unit 
Penelitian dan Pengabdian Masyarakat (PPM) Universitas Telkom yang telah memberikan hibah pengabdian masyarakat sehingga terlaksana kegiatan pelatihan ini.

\section{DAFTAR PUSTAKA}

[1] Lalley, J. P. \& Miller, R.H. (2007). The learning pyramid: Does it point teachers in the right direction? Education, 128(1), 64-79

[2] Palopa, I. (2015). Pengembangan Model Pembelajaran Partisipatif Andragogis Untuk Meningkatkan Hasil Belajar Warga Belajar. Jurnal Irfani, 11 (1), 59-88 